\title{
THE AFRICAN CONTINENTAL FREE TRADE AREA AND ITS EMPLOYMENT-GENERATION POTENTIALS IN NIGERIA'S INDUSTRIAL SECTOR
}

\author{
Oziengbe Scott AIGHEYISI \\ Institute of Health Technology \\ University of Benin Teaching Hospital \\ Benin City, Nigeria. \\ oziengbeaigheyisi@gmail.com
}

\begin{abstract}
The study empirically examines the employment generation potentials of the African Continental Free Trade Area (AfCFTA) in Nigeria's industrial sector. The ARDL approach to cointegration and error correction modeling is employed for analysis of annual time series data covering the period 19912020. The study finds inter alia that the short run effect of expansion of intra-African trade (expected to result from the AfCFTA) on industrial sector employment is positive and statistically significant. The long run effect is also positive, but not statistically significant. It also finds that trade openness integration of the economy with the global market - significantly enhances employment generation in the nation's industrial sector in the long run; though the short run effect is negative and significant. These suggest that the country's membership of the AfCFTA and implementation of policies aimed at (cautiously) deepening the integration of the economy with the global market should be considered as supplementary avenues to achieving (sustainable) employment generation in the nation's industrial sector in the short-and long-run. Other evidence-based policy recommendations are discussed.
\end{abstract}

Keywords: African Continental Free Trade Area, Intra-African Trade, Global Trade, Industrial Sector, Employment, Unemployment.

JEL Codes: E24, F13, F14, F15, L60

\section{Introduction}

The African Continental Free Trade Area (AfCFTA) was conceived to expand or intensify trade among African countries by removing barriers to trade flows among them. It envisages eliminating tariffs on more than $90 \%$ of tradable goods in the continent (Songwe, 2019).

One of the anticipated benefits of implementing the African Continental Free Trade Agreement is that it will engender improvement in employment levels in participating countries (World Bank, 2020a). The eighth goal of the United Nations Sustainable Development Goals (SDG-8) has to do with achieving full and productive employment and decent work for all by the year 2030 (United Nations, 2021). Similarly, the first priority areas of the first goal of the African Union Agenda 2063 (which has to do with attainment of high standard of living, quality of life and wellbeing for all citizens) are the issues of income, jobs and decent works (African Union, 2021). Thus, at the hearts of the AfCFTA, the UNSDGs and the African Union Agenda 2063 is the issue of employment generation. The AfCFTA

License: Authors of papers retain copyright and release the work under a Creative Commons Attribution-NonCommercial-ShareAlike 4.0 International License (c) (i) (2) (CC BY-NC-SA 4.0). 
may therefore be seen as a potential tool for achieving the eighth UNSDG and the first goal of the African Union Agenda 2063.

The UNCTAD (2020) predicts positive effect of trade on employment as export can engender increase in income by expanding markets for goods and services of firms and boosting their profitability and production potentials, thereby engendering demand for more labour. Import is also expected to increase the inflow of knowledge and other production inputs (including machinery, equipment or advanced technologies) which also have the potentials to enhance labour demand, particularly high-skilled labour as a result of their potential positive effect on production and income. However, Ubaldo and Winters (2020) argued that trade should not be expected to have overall positive effects on employment in all sectors considering that trade policies differ from employment policies. According to them, jobs are created in sectors of the economy protected and promoted by trade regulations. Thus trade regulations can cause job creation in one sector while causing job destruction in another sector.

One of the sectors of the Nigerian economy that could be relied upon to achieve the SDG-8 and the African Union Agenda-1 is the industrial sector from which goods are produced, and which contributes significantly to the country's gross domestic product (GDP). The World Bank (2020) envisages a boost in Africa's manufactured exports following the implementation of the African Continental Free Trade Agreement. Manufactured exports are produced in the manufacturing sector which is a key sub-sector of the industrial sector. The sustainability of the performance of the industrial sector depends to a large extent on the size and quality of the labour force employed therein. Employment in the sector is a major determinant of the level of output therefrom. This is in line with the predictions of various production functions and economic growth theories. The industrial sector is expected to be productive and to have the capacity to engage a large percentage of a nation's labour force. However, this has not been the case with Nigeria's Industrial sector which employs the lowest proportion of total employment among the three main sectors of the economy namely agriculture, industry and services sectors. It is against this backdrop that this paper examines the (potential) effects of increased intraAfrican trade (expected to result from the implementation of the AfCFTA) on employment generation in one of Africa's largest economy - Nigeria, focusing on the industrial sector in view of its relevance to achieving sustainable growth and development. Thus the objective of the paper is to examine the employment generation potential of the implementation of the AfCFTA on employment generation in Nigeria's industrial sector. The study is novel because to my knowledge based on a wide search of the literature, no previous study has investigated the implication of the AfCFTA for employment generation in Nigeria's industrial sector. Thus, the study contributes to the trade literature by investigating the effect of implementation of a free trade area on sectoral employment generation in a developing country as Nigeria.

\section{Brief Background of Study}

For over forty years, trade among African countries (that is, intra-African trade) has been quite low compared to trade between African countries and other regions of the world (that is, extra-African trade). According to UNCTAD (2019), between 2015 and 2017, intra-African trade constituted about $2 \%$ of the continent's total trade, compared to other continents such as the Americas (47\%), Asia $(61 \%)$, Europe (67\%), and Oceania or Australia (7\%). In 2017, intra-African export was $16.6 \%$ of the continent's total exports. The continent's exports to other regions ranged between $80 \%$ and $90 \%$ of total exports. Intra-continental export was $68.1 \%$ of total exports in Europe. In Asia it was $59.4 \%$. In America it was $55.0 \%$ and in Oceania it was $7.0 \%$ (UNCTAD, 2019). Interestingly, in 2019 none of the top ten major African exporting countries (which are also among the largest economies in Africa according to the IMF (2019) country rankings by GDP size) were listed among the top ten leading intra-African exporters some of which are listed among the poorest countries in the continent 1 (UNCTAD, 2019; Workman, 2019; Ojekunle, 2019).

\footnotetext{
${ }^{1}$ According to the World Trade Organisation cited in Workman (2019) and Ojekunle (2019), Africa's top 10 exporters include South Africa, Nigeria, Angola, Algeria, Libya, Egypt, Morocco, Ghana, Tunisia and Ivory Coast. The UNCTAD (2019) identifies Eswatini, Namibia, Zimbabwe, Uganda, Togo, Senegal, Djibouti, Lesotho, Kenya and Malawi as the top 10 intra-African exporters. Several of Africa's top 10 exporters such as Uganda, Togo, Senegal, Djibouti, Lesotho were also listed among the poorest countries in the continent in 2020 (Ventura, 2020). This implies that intra-African export trade has been partly driven by some of the continent's poorest countries.
} 
The foregoing reveals that the continent is highly dependent on trade with the rest of the world (UNCTAD, 2019). Though intra-African trade rose rapidly between 2000 and 2018 (as shown in Figure 1) and was driven mainly by industrial product and manufactured goods (AFREXIM, 2019) before declining in the 2019/2020 period, the gap between the relative shares of intra-African and extra-African trade has been quite enormous. This is shown in Figure 2.

Figure 1: Trends in Intra-African Trade

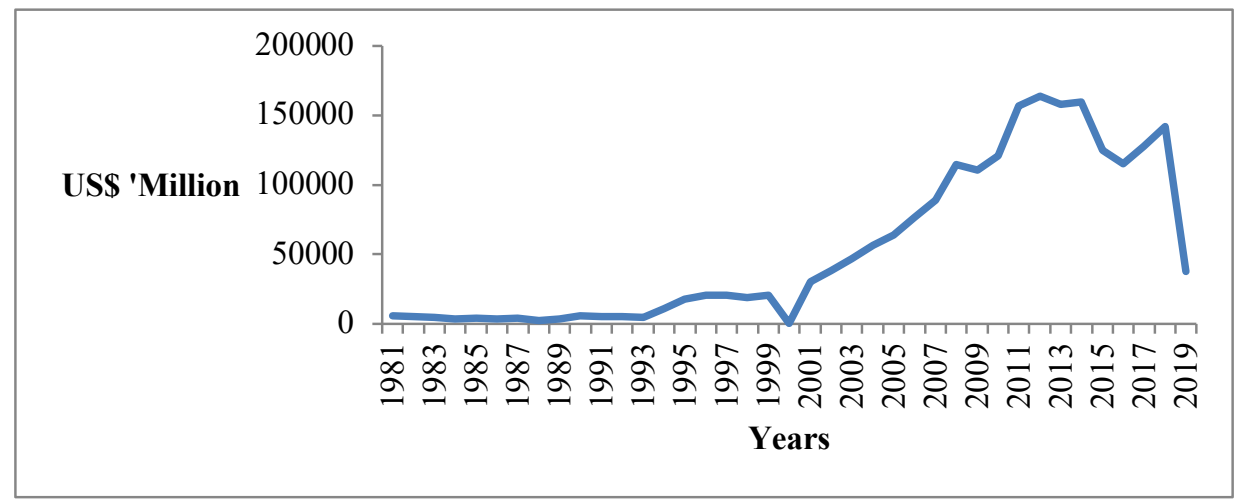

Figure 2: Trends in Relative Shares of Intra-African and Extra-African Trade in Africa's Total Trade

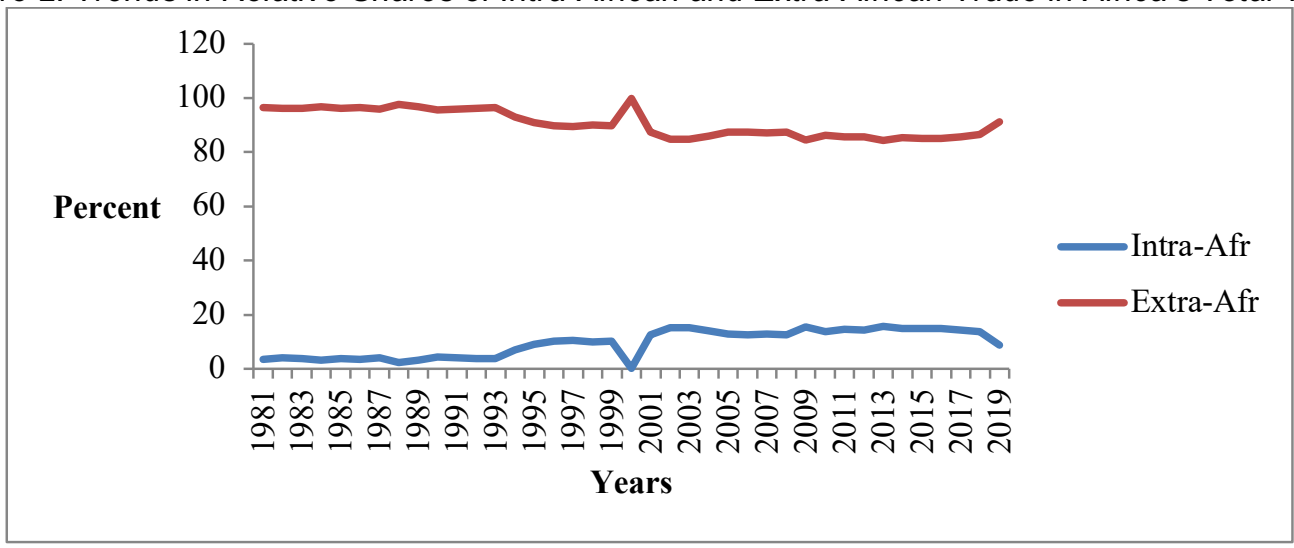

Intra-Afr stands for the share of intra-African trade in Africa's total trade

Extra-Afr stands for share of extra-African trade in Africa's total trade

Source: United Nations University-Comparative Regional Integration Studies, Regional Integration Knowledge System (UNU-CRIS RIKS), 2020.

Mismanagement of economic policies, poor infrastructure and internal political tensions have been identified as some of the factors adversely affecting intra-African trade (Longo \& Sekkat, 2004). Other factors that may have been responsible for the relatively low volume of intra-African trade are low level of investment, low volume and quality of industrial and non-industrial output, weak commitment of member countries to regional economic blocs within the continent, differences in the level of development of countries in the continent as 33 out of the 54 countries therein are classified as LDCs (UNCTAD, 2019), preferences or taste for foreign goods (responsible for high demand for imports from highly industrialized economies), desire to earn more foreign exchange from the advanced economies and to copy their technologies (these are also partly responsible for higher volume of extra-African exports) etc.

Items of trade among African countries include food and other agricultural products and a few industrial products and manufactured products which have remained the main contributors to the value of trade in the continent (UNCTAD, 2019; AFREXIM, 2019).

Nigeria's economy is currently Africa's largest economy in terms of GDP size (World Population Review, 2021). It is also one of the continent's largest exporters, though the country is not listed among the top 10 intra-African exporters. According to OEC (2021, para. 1), as at 2019, the country's major export items were "Crude Petroleum $(\$ 46 B)$, Petroleum Gas $(\$ 7.78 B)$, Scrap Vessels $(\$ 2.26 B)$, 
Flexible Metal Tubing (\$2.1B), and Cocoa Beans $(\$ 715 \mathrm{M})$, exporting mostly to India $(\$ 10.5 \mathrm{~B})$, Spain $(\$ 6.32 \mathrm{~B})$, United States $(\$ 4.68 \mathrm{~B})$, France $(\$ 4.37 \mathrm{~B})$, and Ghana (\$4.04B)”. The country's industrial sector is driven mainly by the crude oil subsector, though the Government is currently making effort to revamp the manufacturing, and mining and solid minerals subsectors which have been underperforming and underutilized as a result of years of neglect despite their vast potentials as income and employment generators.

In spite of the Government's effort to revamp the industrial sector, the sector has remained weak, generally. The weakness accounts largely for the low volume of non-oil industrial and manufactured exports, and the high volume of industrial and manufactured imports as a result of inadequate industrial production. Consequently, employment generating potential of the sector has not been fully harnessed.

In Nigeria, industrial sector share of the total employment (in the three key sectors namely, agriculture, industry and services) has been the lowest. This is in spite of the fact that it is the second largest contributor to the GDP, after the services sector (Aigheyisi \& lyoha, 2020). The trends in the relative shares of sectoral employment in the country are shown in Figure 3.

Figure 3: Relative shares of agriculture, industry and services employments in total employment in Nigeria

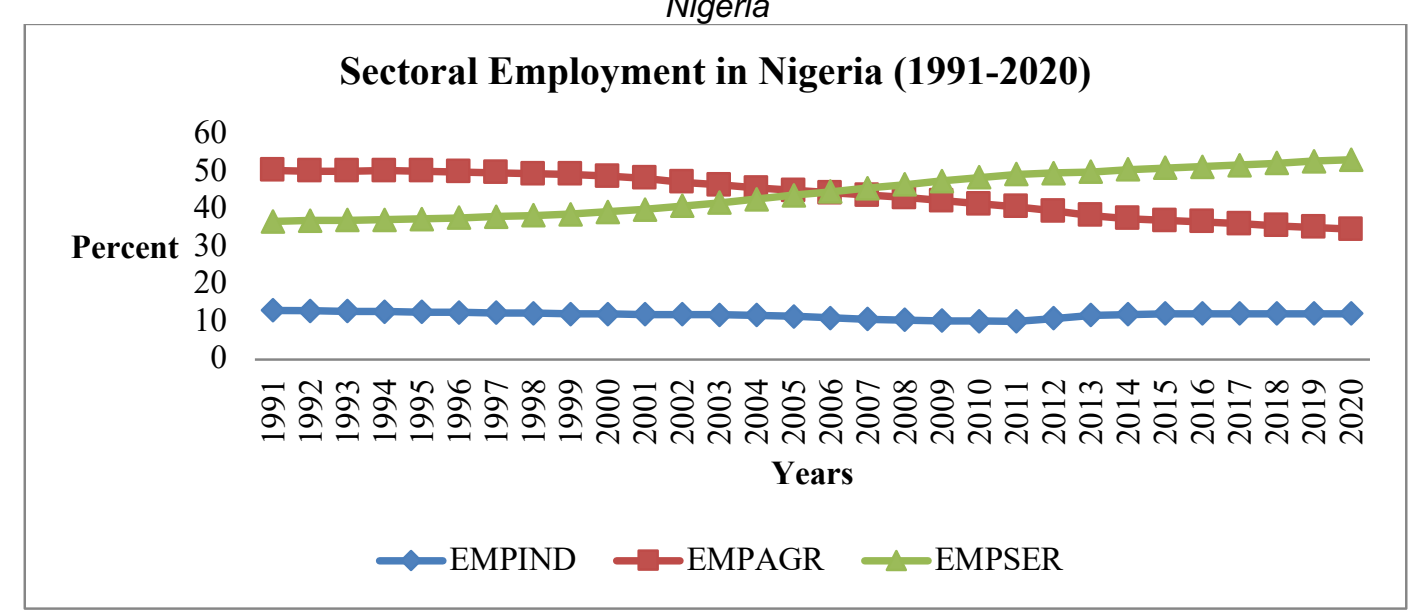

The relatively low contribution of industrial sector employment to total employment in Nigeria may be attributed to its near moribund state as many manufacturing firms have either shut down operations permanently or relocated to other (neighboring African countries) as a result of unfavourable business environment marked by high cost of doing business, weak or poorly developed infrastructure, heightened insecurity, etc.

Nigeria's Government recently signed the Free Trade Agreement in 2019 to be part of the AfCFTA after a long period of hesitation. This move was made in view of the anticipated benefits of joining the AfCFTA which include improvement in investment, poverty reduction, job creation, etc. This study examines the potentials of intra-African trade expansion which is the main aim of the AfCFTA, to stimulate employment in Nigeria's industrial sector.

\section{Literature Review}

This section presents a review of the theoretical and empirical literature on the nexus between international trade and employment. This is done to highlight the theoretical underpinnings and the previous empirical findings on the relationship.

\section{Theoretical Literature Review}

The level of employment in a country is determined by both supply-side and demand-side factors. A major determinant of labour supply is the wage rate. In the absence of deliberate unemployment, increase in wage rate is associated with increase in labour supply. The demand-side factors include factors such as productivity, profitability, and output or economic growth. These factors are affected 
by numerous factors including international trade. The extent to which trade affects employment is dependent on the extent to which it affects the factors affecting supply of, and demand for labour.

There is no consensus in theoretical literature on the relationship between trade and employment. The optimistic view is that trade engenders division of labour, expansion of markets for goods and services, and acquisition of knowledge and foreign technology which enhance productivity leading to increase in wages and boost in production, thereby engendering increased demand for labour where there is sustained effective demand (Matusz, 1996; Felbermayr, et al., 2008). There is also the pessimistic view that international trade could have adverse effect on employment particularly in less developed countries with weak industrial sector and high import penetration rates resulting from high import demand due to low level of domestic output. Employment levels in countries with low absorptive capacities, weak industrial sector and low manufacturing capacity utilisation, low research and development (R\&D) capabilities, low volume and quality of output, low volume and quality of exports, low economic complexity, high dependence on imports, etc. will be adversely affected by international trade (Aigheyisi, 2019a). Then there are those who do not envisage any significant or direct relationship between international trade and overall employment. Their argument is that international trade may enhance employment generation in some sectors (particularly where the sectors in which a country has comparative advantage), and cause job destruction in other sectors, resulting in a non-significant effect on overall employment levels (Ubaldo \&Winters, 2020).

The UNCTAD (2013) links the effect of trade on employment to its effect on economic growth. Increase in employment results from positive effect of trade on productivity which enhances economic growth. However, when trade adversely affects economic growth, then employment may be adversely affected; whereas when trade does not affect growth, employment may be unaffected by trade.

The gains from trade are also dependent on the level of development of the trading partner(s). All things being equal, with favourable trade agreements, the gains accruing to developing countries from trading with developed countries may be substantially larger than the gains resulting from trade between or among developing countries. Several reasons could be adduced for this. The learning potentials or benefits (learning by exporting) and other positive spillover effects such as importsengendered knowledge and technology transmission effects which enhance productivity and economic growth leading to reduction in unemployment or improvement in employment, as predicted by the Okun's Law and the Keynesian theory of income, output and employment respectively, from the latter are much larger in trade between developed and developing countries.

\section{Empirical Literature Review}

The empirical literature has been inconclusive. Several of the studies found inverse relationship between trade and employment (Dutt, et al., 2008; Campos-Vázquez \& Rodríguez-López, 2011; Nchom \& Udeorah (2021)). Others found positive effect of trade on employment (Polat \& Uslu, 2011; Anyanwu, 2014; Kpognon, et al., 2020). Non-significant effect of trade on total employment was found in Yanikkaya, 2013; Rajesh \& Subash, 2015). However, Kim (2011) and Kpognon, et al. (2020) attribute the effect of trade on employment on rigidity or flexibility of the labour market arguing that trade positively affects employment where labour market institutions are flexible. Several of the previous studies examined the effects of exports and import components of trade on employment (Herath, 2014; Akkus, 2018; Aigheyisi, 2019). A common strand in the literature is that exports (intensity) positively affect employment, while imports (penetration) adversely affect employment especially in developing countries. The empirical evidence from previous studies is discussed in this section to highlight findings from previous related studies and to identify the gaps in the literature which the current paper intends to fill.

Dutt, et al. (2008) employed various panel modeling techniques including pooled OLS and instrumental variable techniques to investigate the effect of trade on unemployment during the period 1990-2000 using cross-national data. The study found that trade openness was negatively related to unemployment. This implies that trade openness significantly reduced unemployment (or helped to improve employment). Trade protection was found to be positive relatively related to unemployment, implying that protection tended to increase unemployment (or reduce employment). Based on these findings, it can be inferred that trade liberalization policies would help reduce unemployment or improve employment. 
Polat and Uslu (2011) examined the effect of international trade on manufacturing sector employment in Turkey using panel dataset on 95 manufacturing firms covering the period 1992-2001, using the system generalized method of moments (GMM). The study found that manufacturing employment was positively affected by increase in output, but adversely affected by increase in wages. On the employment effects of trade variables, the study found no significant contemporaneous effects of export intensity and import penetration on manufacturing sector employment. Current level of manufacturing employment was significantly affected by trade variables with lags, the lagged effect of export intensity being positive, and that of import penetration being negative.

The effect of trade on occupational employment in Mexico during the period 1992 -2009 with regard to its membership of the North American Free Trade Area (NAFTA) was examined in Campos-Vázquez and Rodríguez-López (2011). The study found that reduction in trade costs (resulting in trade expansion and intensity) was associated with improvement in low-skilled occupational employment in the country.

Kim (2011) investigated the effect of international trade on aggregate unemployment in 20 OECD countries, taking account of the roles of labour market institutions during the period 1961-2008. The study found that international trade was associated with increase in unemployment where labour market institutions were rigid. It also found that international trade was associated with reduction in unemployment where labour market institutions were more flexible. Further evidence from the study was that international trade had no significant effect on employment in the presence of moderate or average degree of rigidities of the labour market. Thus the effect of international trade on unemployment in the OECD was dependent on the degree of rigidity or flexibility of labour market institutions.

Yanikkaya (2013) investigated the effect of trade openness on employment in developed and developing countries in panel settings. The study found that the overall effect of trade openness on aggregate employment in developing countries is quite weak. The weakness was attributed to the poor response of output to employment in the countries. However, at the sectoral level, trade openness was found to impact positively and significantly on industrial employment in the developing countries and negatively on industrial employment in developed countries. It was also found that trade restrictions or barriers adversely affect employment creation in the services sector of developed countries.

Anyanwu (2014) examined the effects of intra-African trade on male, female and aggregate youth unemployment in the continent using cross-sectional time series data covering the period 1980-2010. The study found that intra-African trade significantly reduces youth unemployment in the continent. It further found that inflation, economic growth, secondary school education, higher urbanization rate and institutionalized democracy significantly reduced youth unemployment in the continent. However, real per capita income and credit to the private were found to be associated with escalation of unemployment, FDI and government consumption expenditure exerted no significant effect on youth unemployment in the continent.

The effect of international trade on employment generation in Sri Lanka during the period 1990-2012 was examined in Herath (2014). To achieve the objectives, the effects of export intensity, import penetration and trade weighted tariffs were examined. The employment effects of other variables serving as control variables in the study such as FDI, capital-labour ratio, GDP and real wages were also investigated. The OLS technique was employed to estimate a multiple regression model. The study found that export intensity was positively and significantly related employment, while import penetration was negatively and significantly related to employment. The effects of tariff, FDI and real wages on employment were found to be statistically non-significant. Furthermore positive and significant relationship was found between capital-labour ratio and employment, while inverse relationship was found between GDP and employment, contrary to expectation.

Rajesh and Subash (2015) examined the effect of international trade on manufacturing employment in India during the period 1980-2005 using industry level panel dataset. Various panel modeling techniques including OLS, fixed effect and system GMM were employed. Evidence from the study suggests no significant effect of international trade on employment generation in the country. 
In a study on the impact of international trade on employment in Korea, Jha, et al. (2019) investigated the effect of reduction in input trade cost on employment in Korean firms during the period 2006-2016, taking into account the role of net substitutability between inputs which was measured as the difference between elasticity of input substitution and elasticity of output substitution. The study found that decrease in input trade cost was associated with decrease in employment and the effect increased with greater net substitutability between inputs. The study further found that in industries with lower net substitutability among inputs, exporting and importing were quite favourable to employment generation in the country though the employment generation effect of exporting was greater.

Akkus (2018) examined the effects of trade and productivity on manufacturing sector employment in Turkey during the period 2003-2010 within panel setting. The methodology employed was the fixed effect dummy variable technique. The study found that exports positively affected manufacturing sector employment, while import penetration adversely affected employment in the sector. Increase in wages also adversely affected employment generation in the sector, while the employment effect of labour productivity in the sector was positive but statistically not significant.

Kpognon, et al. (2020) examined the effect of trade openness on youth employment in sub-Sahara Africa (SSA) during the period 2002-2017 using pooled least squares and IV-2SLS technique to account to endogeneity of the regressors. The study found positive and significant effect of trade openness on youth employment in the continent, generally. However, as found in the study by Kim (2011) for OECD, the effect of trade openness on employment in SSA countries with rigid labour markets was negative and significant.

Idris, et al. (2020) examined the effect of high technology trade on employment in 20 high-tech exporting countries during the period 2007-2016. The study found negative effect of high-tech trade on employment in the countries. The study therefore called for appropriate policies to address the decrease in employment engendered by high-tech trade in the countries.

The effect of exports and imports on employment in Nigeria during the period 1999-2019 was examined in the study by Nchom and Udeorah (2021) using the dynamic ordinary least squares (DOLS) technique. The study found negative, significant effects of both components of trade on employment in the country. The implication of the findings is that trade adversely affects employment generation in the country.

From the literature review, it can be observed that most of the previously related studies either focused on the effect of trade on aggregate employment (or unemployment) or the effect of trade on manufacturing sector employment. To my knowledge based on a wide search of the literature, no previous study has examined the effect of intra-continental trade on employment in a country's industrial sector. A gap therefore exists in the literature. This study contributes to the extant literature by examining the effect of expansion in intra-African trade (which is the target of the AfCFTA) on employment in Nigeria's industrial sector (comprising the manufacturing sector, mining, oil and gas subsectors, etc.) in view of the relevance of the sector to the country's economic growth and sustainable development.

Whereas most of the previous studies involved panel data analysis, this study opts for time series analysis, using time series data on total intra-African trade since its objective is to examine the potential effect of expansion of trade within the continent (in line with AfCFTA's vision of creating a single (integrated) African market (UNCTAD, 2019)) on industrial sector employment in Nigeria.

\section{Methodology}

\section{Data}

Data used for the study are annual time series data spanning the period from 1991 to 2020 . The data were sourced from the World Bank (2020b) and the UNU-CRIS RIKS (2020). Data on intra-African trade were obtained from the RIKS, while data on other variables were obtained from the WDI. The scope was dictated by data availability as available data on the key independent (explanatory) variable of interest which is industrial sector share of total employment begins from 1991. The descriptions of the variables are presented in Table 1. 
Table 1: Description of Variables

\begin{tabular}{|l|l|}
\hline Variables & Description and Measurement \\
\hline EMPIND & $\begin{array}{l}\text { Industrial sector share of total employment, measured as the proportion of } \\
\text { employment in industrial sector in total employment. This is the dependent } \\
\text { variable. }\end{array}$ \\
\hline IAT & $\begin{array}{l}\text { Intra-African trade, measured as sum of total intra-African exports value } \\
\text { and intra-African imports value }\end{array}$ \\
\hline REXRT & $\begin{array}{l}\text { Real effective exchange rate, measured as the nominal effective exchange } \\
\text { rate divided by index of cost. }\end{array}$ \\
\hline TOPEN & $\begin{array}{l}\text { Trade openness, measured as total trade (total exports plus total imports) as } \\
\text { a percentage of GDP. }\end{array}$ \\
\hline FDIY & $\begin{array}{l}\text { Net foreign direct investment, measured as net foreign direct investment as } \\
\text { a percentage of GDP. }\end{array}$ \\
\hline URBPG & $\begin{array}{l}\text { Inflation, measured as annual percentage change in consumer price index. } \\
\text { population. }\end{array}$ \\
\hline
\end{tabular}

\section{Theoretical Framework and Model}

The study adopts the theoretical framework developed in Anyanwu (2014), which also builds on the frameworks developed in Kim (2011), Choudhry et al. (2012) The framework hypothesized youth employment in Africa to be affected by factors such as trade openness, inflation, per capita income, urbanization rate, FDI, credit to private sector government consumption expenditure and other variables. This study differs from the previous studies by investigating the effect of intra-African trade on industrial sector employment (in Nigeria) instead of aggregate employment or manufacturing sector employment (which is a part of industrial sector employment) incorporated in previous models. The functional form of the study model is specified as:

$$
\text { EMPIND = } f(I A T, \text { REXRT, TOPEN, FDIY, INF, URBPG) }
$$

The variables are as described and measured above. The autoregressive distributed lag (ARDL) modeling also known as the bounds test approach to cointegration and error correction modeling (ECM) developed by Pesaran, et al. (2001) was employed in this study. This choice of this methodology was informed by the facts that it is applicable in cases of variables with mixed order of integration - that is a combination of variables are level stationary $[\mathrm{l}(0)]$ and first differenced stationary [I(1)], so long as none of the variables is integrated of order 2 [I(2)]. It is also applicable in cases of small and finite dataset. Furthermore, the method yields consistent and efficient long run estimates with valid t-ratio even in the presence of regressors' endogeneity peculiar with cointegrated regressors (Harris \& Sollis, 2003; Akbota \& Baek, 2018).

Operationalisation of the ARDL bounds test involves OLS-estimation of an unrestricted error correction (UEC) version of the ARDL model specified as:

$$
\begin{aligned}
& \Delta \text { EMPIND }_{\mathrm{t}}=\beta_{0}+\sum_{\mathrm{j}=1}^{\mathrm{p}}\left(\beta_{1 \mathrm{j}} \Delta \text { EMPIND }_{\mathrm{t}-\mathrm{j}}\right)+\sum_{\mathrm{j}=0}^{\mathrm{p}}\left(\beta_{2 \mathrm{j}} \Delta \operatorname{LnIAT}_{\mathrm{t}-\mathrm{j}}\right)+\sum_{\mathrm{j}=0}^{\mathrm{p}}\left(\beta_{3 \mathrm{j}} \Delta \mathrm{REXRT}_{\mathrm{t}-\mathrm{j}}\right)+ \\
& \sum_{\mathrm{j}=0}^{\mathrm{P}}\left(\beta_{4 \mathrm{j}} \Delta \text { TOPEN }_{\mathrm{t}-\mathrm{j}}\right)+\sum_{\mathrm{j}=0}^{\mathrm{P}}\left(\beta_{5 \mathrm{j}} \Delta \mathrm{FDIY}_{\mathrm{t}-\mathrm{j}}\right)+\sum_{\mathrm{j}=0}^{\mathrm{P}}\left(\beta_{6 j} \Delta \mathrm{INF}_{\mathrm{t}-\mathrm{j}}\right)+\sum_{\mathrm{j}=0}^{\mathrm{P}}\left(\beta_{7 \mathrm{j}} \Delta \mathrm{URBPG}_{\mathrm{t}-\mathrm{j}}\right)+ \\
& \delta_{1} \text { LnIAT }_{\mathrm{t}-1}+\delta_{2} \text { REXRT }_{\mathrm{t}-1}+\delta_{3} \text { TOPEN }_{\mathrm{t}-1}+\delta_{4} \text { FDIY }_{\mathrm{t}-1}+\delta_{5} \mathrm{INF}_{\mathrm{t}-1}+\delta_{6} \mathrm{URBPG}_{\mathrm{t}-1}+\xi_{t}
\end{aligned}
$$

Ln stands for natural logarithm. $\delta 1$ to $\delta 6$ correspond to the long run relationship, while $\beta 2 \mathrm{j} \ldots \beta 7 \mathrm{j}$ correspond to the short run relationships. $\Delta$ is the first difference operator, $\xi$ is the error term.

The joint significance of the estimated UEC-ARDL model is tested using the Wald's F-test. The null hypothesis $(\delta 1=\delta 2=\delta 3=\delta 4=\delta 5=\delta 6=0)$ which implies "No long-run relationships exist" is tested against the alternative hypothesis $(\delta 1 \neq \delta 2 \neq \delta 3 \neq \delta 4 \neq \delta 5 \neq \delta 6 \neq 0)$. Pesaran, et al. (2001) computed two sets of asymptotic critical values for the F-statistic at different levels of statistical significance. One 
set comprises the lower bound critical values (LB) while the other set comprises the upper bound critical values (UB). The decision rule is:

F-stat. > UB, reject null hypothesis

F-stat. $<$ LB, do not reject null hypothesis

$\mathrm{LB}<\mathrm{F}$-statistic $<\mathrm{UB}$, test is inconclusive

The error-correction model $(\mathrm{ECM})$ is derived as:

$$
\begin{aligned}
& \Delta \text { EMPIND }_{\mathrm{t}}=\mathrm{a}_{0}+\sum_{\mathrm{j}=1}^{\eta}\left(\mathrm{a}_{1 \mathrm{j}} \Delta \text { EMPIND }_{\mathrm{t}-\mathrm{j}}\right)+\sum_{\mathrm{j}=0}^{\eta}\left(\mathrm{a}_{2 \mathrm{j}} \Delta \operatorname{LnIAT}_{\mathrm{t}-\mathrm{j}}\right)+\sum_{\mathrm{j}=0}^{\eta}\left(\mathrm{a}_{3 \mathrm{j}} \Delta \mathrm{REXRT}_{\mathrm{t}-\mathrm{j}}\right)+ \\
& \sum_{\varepsilon_{t}=0}^{\eta}\left(\mathrm{a}_{4 \mathrm{j}} \Delta \text { TOPEN }_{\mathrm{t}-\mathrm{j}}\right)+\sum_{\mathrm{j}=0}^{\eta}\left(\mathrm{a}_{5 \mathrm{j}} \Delta \text { FDIY }_{\mathrm{t}-\mathrm{j}}\right)+\sum_{\mathrm{j}=0}^{\eta}\left(\mathrm{a}_{6 \mathrm{j}} \Delta \mathrm{INF}_{\mathrm{t}-\mathrm{j}}\right)+\sum_{\mathrm{j}=0}^{\eta}\left(\mathrm{a}_{7 \mathrm{j}} \Delta \mathrm{URBPG}_{\mathrm{t}-\mathrm{j}}\right)+\omega \mathrm{ECT}_{t-1}+
\end{aligned}
$$

The $a 2 \mathrm{j}$ - a7j represent estimates of the respective short run effects of intra-African trade and other independent variables on industrial sector share of total employment. ECT represents the error correction term. Its coefficient $(\omega)$ measures the speed of adjustment to equilibrium in the event of short run deviations therefrom, and it is expected to be negatively signed and statistically significant to play the error correction role. The negative sign and statistical significance further confirms cointegration relationship. $\varepsilon$ represents the residuals.

The steady state (long run) equation is derived as:

EMPIND $_{\mathrm{t}}=\pi_{0}+\pi_{1} \operatorname{LnIAT}_{\mathrm{t}}+\pi_{2}$ REXRT $_{\mathrm{t}}+\pi_{3}$ TOPEN $_{\mathrm{t}}+\pi_{4}$ FDIY $_{\mathrm{t}}+\pi_{5} \mathrm{INF}_{\mathrm{t}}+\pi_{6} \mathrm{URBPG}_{\mathrm{t}}+\mu_{\mathrm{t}}$

[4]

$\pi 1, \pi 2, \pi 3, \pi 4, \pi 5$ and $\pi 6$ are estimates of the respective long run effects of the independent variables on the industrial sector employment. $\mu$ represents the model's residuals.

The a priori expectations are: $\pi 1>0, \pi 2<0, \pi 3>0, \pi 4>0, \pi 5</>0, \pi 6<>>0$.

\section{Theoretical Justifications of A priori Expectations}

Removal of barriers to free flow of trade across national boundaries in Africa is expected to boost trade in the continent. All things being equal, increase in intra-African trade would engender expansion in output of countries participating in the free trade agreement and this in turn would lead to increase in employment. Thus, the coefficient of intra-African trade variable, $\pi 1$ is expected to be positive.

Increase in real exchange rate engenders reduction in cost of imports, leading to increase in inflow of imports of various items (which are relatively cheaper than locally produced items) to an economy (Kemal \& Qadir, 2005; Kharroubi, 2011). Net export is also adversely affected as prices of a country's export items are relatively higher as a result of increase in the real exchange rate. These could adversely affect the domestic (infant) industries, particularly those with low absorptive capacity and those that lack the capacity to compete globally. The result would be decrease in demand for labour, wage-cut, staff and layoff. Hence, the sign on the coefficient of real exchange rate variable is expected to be negative.

Based on theoretical predictions, integration of an economy with the global market indicated by the measure of trade openness is expected to positively affect employment generation in the industrial sector. This is premised on the expectation of positive effect of global trade on a country's economic activities and economic growth in the long run.

Where FDI inflow is complementary to domestic investment in an economy, it raises the stock of capital therein. Various growth theories (neoclassical and endogenous) predict positive effect of capital on economic growth (Solow, 1956; Frankel, 1962, etc.), and growth is predicted to reduce unemployment (according to the Okun's Law) or increase employment (according to the Keynesian theory of income and employment). Hence, all things being equal, FDI inflows to the economy is expected to enhance employment generation in the nation's industrial sector directly (through inflow to the industrial sector) and indirectly (through inflow to other sectors where it engenders increase in effective demand for output of the industrial sector leading to demand for more labour in the sector). 
Complex linkages exist between inflation and employment. The short run Philips curve suggested an inverse relationship between inflation and unemployment during the period 1861-1957 in the United Kingdom (Philips, 1958). Increase in inflation was associated with decrease in unemployment. This to some extent implies that inflation could be favourable to employment generation in the short run. Anyanwu (2014) explains this relationship by attributing the short-run positive relationship between inflation and employment to increase in spending which could cause inflation and boost employment (or reduce unemployment) simultaneously. However, the Philips curve relation has been described by Tobin (1972) as an empirical finding seeking a theory. Wadhwani (1987) found that higher inflation contributed to lower employment in same country (the United Kingdom). Dorn (2020, p.134) described the Phillips curve as "a poor guide for monetary policy (which) ... continues to misinform policy makers, and lead them astray". Low or moderate inflation (contrary to deflation) may be favorable to output expansion and employment generation. Inflation expectation may cause increase in demand for labour in the face of rising prices to be engaged for production in current period so as to reap higher profits when prices of currently produced (durable) output eventually rise as expected. High inflation raises the cost of production, thereby discouraging production and reducing demand for labour. It also reduces the competitiveness of a country's industrial output in both domestic and foreign markets, causing increase in imports and adversely affecting export. Where these transpire, employment in the nation's industry may be adversely affected.

The study uses urban population growth instead of (total) population growth for two reasons. First, during the preliminary tests of this study, population growth was found to be strongly correlated to intra-African trade. This has the potential of introducing the problem of multicollinearity into the model. However, urban population growth was only moderately correlated with intra-African trade, ruling out the possibility of the multicollinearity problem. Second, the urban centres are the base of the industrial sector in Nigeria as most of the industries producing the nation's output are sited therein (ILO, 1996; Wiebusch, 2012; Sanchez-Reaza, et al., 2016). This largely explains the rural-urban migration as people tend to move from the rural areas to the urban areas in search of more gratifying jobs. This, in addition to immigration and births in urban areas also contribute to growth in urban population, which normally would imply increase in the number of consumers of output of industrial firms.

The effect of urban population growth on industrial sector employment is indeterminate. The profitability and productivity of firms are major determinants of demand for labour. Where firms are highly productive and profitable, chances are that they will demand more labour from the supply of labor resulting from the growth in population. Some of the urban dwellers may turn out to become industrialist and employers of labour. However, due to some factors including low profitability as a result of dwindling sales and high cost of production, intense external competition (that is local firms competing with foreign firms for domestic market share), etc., demand for labor may be adversely affected. Consequently, the growth in urban population will only serve to exacerbate the unemployment problem. Unemployment resulting from urban population growth is also associated with increase in crime rate and insecurity in the urban areas (CIA, 2007). These (crime and insecurity) adversely affect foreign and domestic investment (Aigheyisi, 2020b). The decline in investments adversely affects employment generation. Hence the effect of urban population growth on industrial sector employment is indeterminate.

\section{Pre-analysis and Model Diagnostic Tests}

Prior to estimation of the models, the variables were subjected to pairwise correlation analysis to ascertain that pairs of the independent variables are not strongly correlated as they could introduce the problem of multicollinearity which could introduce some bias into the model by inflating the variances of affected parameters, thereby reducing the t-ratios. The implication is variables that are statistically significant will be erroneously taken to be non-significant. Thereafter, the variables were tested for stationarity to ascertain that none of them is I(2). For this, the Kwiatkowski-Phillips-SchmidtShin (KPSS) method was used on account of its suitability to small samples or short time series (Arltová \& Fedorová, 2016). The KPSS test was complemented by the Dickey-Fuller generalized least squares (DF-GLS) test for unit root proposed by Elliott, Rothenberg, and Stock (1996), which modifies the Dickey Fuller test by correcting the problem of serial correlation inherent in time series data using a GLS procedure.

Post model estimation diagnostic test performed include residual normality test using the Jarque-Bera $(\mathrm{JB})$, the serial correlation test using the Breusch-Godfrey (B-G) LM test, the heteroskedasticity test 
using the Breusch-Pagan-Godfrey (B-P-G) test and the test for accuracy of the model specification using the Ramsey's regression equation specification error test (RESET). The study relied on the Cumulative sum of recursive residuals (CUSUM) and cumulative sum of squared recursive residuals (CUSUMSQ) prescribed by Brown, et al. (1975) to test the stability of the model.

\section{Results and Discussion}

Correlation Analysis

The empirical analysis begins with presentation and discussion of the correlation matrix. The matrix is shown in Table 2.

Table 2: Pairwise Correlation Matrix

\begin{tabular}{|c|c|c|c|c|c|c|c|}
\hline & EMPIND & LOG(IAT) & REXRT & TOPEN & FDIY & INF & URBPG \\
\hline EMPIND & 1.0000 & & & & & & \\
\hline LOG(IAT) & -0.5811 & 1.0000 & & & & & \\
\hline REXRT & 0.1289 & 0.0955 & 1.0000 & & & & \\
\hline TOPEN & -0.3367 & -0.2134 & 0.0999 & 1.0000 & & & \\
\hline FDIY & -0.0700 & -0.2461 & -0.4234 & -0.0916 & 1.0000 & & \\
\hline INF & 0.4622 & -0.3787 & -0.0370 & -0.1713 & 0.4592 & 1.0000 & \\
\hline URBPG & -0.7278 & 0.5951 & -0.3764 & 0.1992 & 0.0939 & -0.3876 & 1.0000 \\
\hline
\end{tabular}

Source: Author's computation using EVIEWS 9.

The pairwise correlation coefficients show that the correlation between pairs of the regressors is either weak or moderate. They are all less than 0.6. Thus it is expected that models to be estimated with the variables will not be affected by the problem of multicollinearity which introduces some bias into the model as it inflates the variances of affected variables thereby reducing their t-ratios, leading to erroneous inference of an otherwise significant variable as non-significant.

\section{Stationarity and Cointegration Test}

Since the methodology adopted (ARDL) requires that the variables are either $\mathrm{I}(0)$ or $\mathrm{I}(1)$, but not $\mathrm{I}(2)$ variables, the stationarity test was performed using the KPSS test to ascertain the stationary properties of the variables of the study. This was complemented with the DF-GLS test for unit root. The results of the test are presented in Table 3.

Table 3: Stationarity Tests \& Unit Root Tests

\begin{tabular}{|c|c|c|c|c|c|c|c|}
\hline \multicolumn{8}{|c|}{ KPSS Test (Stationarity Test) } \\
\hline \multirow[t]{2}{*}{ Variables } & \multicolumn{3}{|l|}{ Levels } & \multicolumn{3}{|c|}{$1^{\text {st }}$ Difference } & \multirow[t]{2}{*}{ I(d) } \\
\hline & test Stat & $\begin{array}{l}\text { Critical } \\
\text { Value } \\
(5 \%)\end{array}$ & Inference & test Stat & $\begin{array}{c}\text { Critical } \\
\text { Value } \\
(5 \%)\end{array}$ & Inference & \\
\hline EMPIND & 0.1518 & 0.1460 & NS & 0.0792 & 0.1460 & $S$ & 1 \\
\hline $\mathrm{Ln}(\mathrm{IAT})$ & 0.1233 & 0.1460 & $\mathrm{~S}$ & - & - & - & 0 \\
\hline REXRT & 0.0691 & 0.1460 & $\mathrm{~S}$ & - & - & - & 0 \\
\hline TOPN & 0.1427 & 0.1460 & $\mathrm{~S}$ & - & - & - & 0 \\
\hline FDIY & 0.0743 & 0.1460 & $\mathrm{~S}$ & - & - & - & 0 \\
\hline INF & 0.1194 & 0.1460 & $\mathrm{~S}$ & - & - & - & 0 \\
\hline URBPG & 0.1539 & 0.1460 & NS & 0.0966 & 0.1460 & $\mathrm{~S}$ & 1 \\
\hline \multicolumn{8}{|c|}{ DF-GLS Test (Unit Root Test) } \\
\hline \multirow[t]{2}{*}{ Variables } & \multicolumn{3}{|l|}{ Levels } & \multicolumn{3}{|c|}{$1^{\text {st }}$ Difference } & \multirow[t]{2}{*}{ I(d) } \\
\hline & test Stat & $\begin{array}{c}\text { Critical } \\
\text { Value } \\
(5 \%)\end{array}$ & Inference & test Stat & $\begin{array}{c}\text { Critical } \\
\text { Value } \\
(5 \%)\end{array}$ & Inference & \\
\hline EMPIND & -1.8560 & -1.9534 & NS & 0.0792 & 0.1460 & $S$ & $\mathrm{I}(1)$ \\
\hline $\operatorname{Ln}(\mathrm{IAT})$ & -2.2984 & -1.9534 & $S$ & - & - & - & $\mathrm{I}(0)$ \\
\hline REXRT & -2.3991 & -1.9529 & $S$ & - & - & - & $\mathrm{I}(0)$ \\
\hline TOPN & -2.6065 & -1.9529 & $S$ & - & - & - & $\mathrm{I}(0)$ \\
\hline FDIY & -3.1046 & -1.9529 & $S$ & - & - & - & $\mathrm{I}(0)$ \\
\hline INF & -1.9670 & -1.9534 & $\mathrm{~S}$ & - & - & - & $I(0)$ \\
\hline URBPG & -1.1205 & -3.1900 & NS & 0.0966 & 0.1460 & $S$ & $\mathrm{I}(1)$ \\
\hline
\end{tabular}




$$
\begin{aligned}
& I(d)=\text { order of integration; } N S=\text { Non-stationary; } S=\text { Stationary } \\
& \text { Source: Author's estimation using EVIEWS } 9 .
\end{aligned}
$$

The stationarity and unit root test results indicate that the variables are either $I(0)$ or I(1). Specifically, the results of both tests indicate that the dependent variable and URBPG are I(1), while the other variables are $\mathrm{I}(0)$. Thus the methodology adopted is quite suitable for the analysis. Having established the time series properties of the variable, it was expedient to determine whether long-run relationships exist among the variables. The result of the ARDL (bounds) test is presented in Table 4.

Table 4: ARDL Bounds Test

\begin{tabular}{cccc}
\hline Test stat. & Value & \multicolumn{2}{c}{ Critical Value Bounds (1\% sig. level) } \\
\cline { 3 - 4 } F-stat. & 11.25 & LB & UB \\
\multicolumn{2}{r}{ LB stands for lower bound; UB stands for upper bound } \\
\multicolumn{3}{r}{ Source: Author's estimation using EVIEWS 9. }
\end{tabular}

The result shows that the F-statistic of 11.25 is greater than the (1\% significance level) upper bound critical value of 4.43 . Thus the null hypothesis that no long-run relationship exists among the variables is rejected at the $1 \%$. On the basis of this, it can be inferred that the variables are cointegrated. Since the variables are cointegrated, the short run relationship can be represented with an ECM.

\section{Model Estimation Results}

The ECM showing the short-run relationships between the regressors and the dependent variables is presented in Table 5.

\begin{tabular}{|c|c|c|c|}
\hline \multicolumn{4}{|c|}{ Dependent Variable: $\triangle$ EMPIND } \\
\hline \multicolumn{4}{|c|}{ Selected Model: ARDL(1, 1, 1, 2, 2, 1, 0) } \\
\hline \multicolumn{4}{|l|}{ Sample:1991-2020 } \\
\hline Variable & Coeff. & t-Stat. & Prob. \\
\hline$\Delta \mathrm{LOG}(\mathrm{IAT})$ & 0.1355 & 2.5982 & 0.0233 \\
\hline$\Delta(\mathrm{REXRT})$ & -0.0010 & -1.1782 & 0.2616 \\
\hline$\Delta($ TOPEN $)$ & -0.0138 & -2.8501 & 0.0146 \\
\hline$\Delta($ TOPEN $(-1))$ & -0.0229 & -5.1510 & 0.0002 \\
\hline$\Delta$ (FDIY) & -0.2401 & -5.8348 & 0.0001 \\
\hline$\Delta($ FDIY $(-1))$ & 0.1226 & 2.2548 & 0.0436 \\
\hline$\Delta(\mathrm{INF})$ & -0.0039 & -0.7584 & 0.4628 \\
\hline$\triangle(\mathrm{URBPG})$ & -1.2352 & -4.1049 & 0.0015 \\
\hline CointEq(-1) & -0.3465 & -3.4306 & 0.0050 \\
\hline
\end{tabular}

Table 5: Short-run (Error Correction) Model

The estimated ECM shows that intra-African trade is positively related to employment generation in Nigeria's industrial sector. The relationship is significant at the $2.5 \%$ level. Thus expansion or intensification of intra-African trade will engender job creation in the nation's industrial sector in the short-run. This corroborates Dutt, et al. (2008) and Anyanwu (2014) which also found positive effects of trade on employment. Real exchange rate has no significant effect on industrial sector employment creation in the short run. This is indicated by the non-significant coefficient of the variable. Trade openness adversely affects employment generation in the short-run contemporaneously and with a one-year lag. Thus unguided liberalisation of trade tends to contract (or reduce) the capacities of industrial firms to demand more labour in the short run. FDI adversely affects employment in Nigeria's industrial sector in the short-run, contemporaneously. The effect is highly significant at the $1 \%$ level. This suggests that inflow of FDI through the operations of multinational firms in the country suppresses the capacities of domestic firms to employ or retain labour. A mechanism through which this occurs is intense competition beyond the capacities of domestic infant industries which engenders low profitability owing to dwindling sales, staff downsizing, and firms' closures. Though the lagged effect of FDI is positive and significant, suggesting that there could be some time lag before the positive effect of FDI on industrial sector employment materializes, yet the adverse contemporaneous effect is larger and more significant. This suggests a net adverse effect in the short-run. The short-run effect of inflation on industrial sector share of employment is 
negative, but not significant, suggesting that inflation is not a key factor affecting employment in the sector in the short-run.

The growth of population in the country's urban centres (which are responsible for the largest share of her output or GDP) adversely affects industrial sector share of employment in the short-run. The effect is highly significant even at the $1 \%$ level. This suggests that the growth of urban population had been associated with decline in industrial sector employment relative to employment in the services and agricultural sector in the country. The effect could be attributed to several factors including escalation of crime and insecurity associated with rapid urban population growth which raises the unemployment rate in the country. These vices affect investment, and ultimately affect employment.

The error correction term is negatively signed as expected. It is also significant at the $1 \%$ level. Thus it will act to restore equilibrium relationship in the event of short-run deviation therefrom, albeit, at a slow rate as indicated by the absolute value of its coefficient which suggests that $34.65 \%$ of the deviation is corrected annually to restore the equilibrium relationship.

The coefficient of determination shows that the model has a high goodness of fit as it explains $98.86 \%$ of the variation in industrial sector share of total employment in Nigeria. The F-statistics which passes the significance test at the $1 \%$ shows that the independent variables are jointly significant in explain changes in industrial sector share of employment. The Durbin-Watson (DW) statistic of 1.9388 points out that there is absence of autocorrelation.

The foregoing are discussions on the short-run (dynamic) effects of intra-African trade and other variables on industrial sector share of employment in Nigeria. The long-run (steady-state, permanent) coefficients are presented in Table 6.

Table 6: Long-Run Coefficients based on $\operatorname{ARDL}(1,1,1,2,2,1,0)$

\begin{tabular}{crrr}
\hline Dependent Variable: EMPIND & & & \\
\hline Variable & Coeff. & t-Stat & Prob. \\
\hline LOG(IAT) & 0.1217 & 0.6165 & 0.5491 \\
REXRT & -0.0193 & -2.4820 & 0.0289 \\
TOPEN & 0.0696 & 1.8257 & 0.0929 \\
FDIY & -1.1481 & -5.0824 & 0.0003 \\
INF & 0.0315 & 1.9738 & 0.0719 \\
URBPG & -3.5651 & -2.2368 & 0.0451 \\
C & 27.2717 & 5.1463 & 0.0002 \\
\hline Source: Author's estimation using EVIEWS 9. &
\end{tabular}

Intra-African trade which positively and significantly affects industrial sector employment in the shortrun loses its significant in the long-run. This implies that Nigeria cannot rely on intra-African trade to enhance employment in her industrial sector. This buttresses evidence from Yanikkaya (2013) which also found that the effect of trade on employment in developing countries was quite weak due to weak linkages between trade and economic growth. In Nigeria's case, intra-African trade may be weakly associated with long run growth in Nigeria because of the country's low level of intra-Africa exports. Consequently, the non-significant effect of intra-African trade on employment in the country's industrial sector is not entirely unexpected. This observation may also not be unconnected with the level of development of countries in the continent. 33 out of the 54 countries therein are classified as LDCs (UNCTAD, 2019). Most of the countries in the continent are low-income or lower-middle income countries which still rely heavily on imports (ranging from primary, industrial and other intermediate and final consumer goods) from the advance countries in other continents such as the Americas, Asia and Europe. Moreover, the destinations of their major export items are the advanced or highly industrialised economies and trading with these countries maximizes their gains from trade both in terms of earnings, and knowledge and technology transfers.

The long-run effect of increase in real exchange rate on employment generation in the industrial sector is negative, as expected and significant at the $5 \%$ level. This may be attributed to the increase in imports resulting from decrease in the cost of imports engendered by appreciation (increase) in the real exchange rate. The rise in import poses serious threat to the survival of weak industrial firms which may among other things be forced to downsize, lay-off workers, shut-down operations, etc. This 
result is in sync with the evidence from Lysenko (2018) and Ani, et al. (2019) which also found adverse effect of increase in real exchange rate on manufacturing sector's employment.

In the long-run, trade openness positively and significantly affects employment in the nation's industrial sector. This conforms to a priori expectation. All things being equal, then greater integration of the economy with the global market will engender increase in demand for labour in Nigeria's industrial sector. This buttresses evidence from Nwaka, et al. (2017) which found that trade openness had helped to reduce unemployment (or enhance employment) in Nigeria.

The long-run effect of FDI on industrial sector share of employment is negative and significant even at the $1 \%$ level. Thus, as in the short-run, FDI also adversely affects employment in Nigeria's industrial sector in the long-run. The reasons are same as the reasons adduced for the contemporaneous adverse short-run effect. This evidence corroborates evidence from Onimisi (2014) which also found negative effect of FDI on employment in Nigeria.

Inflation positively affects industrial sector employment in the long run. The effect is however significant at the $10 \%$ level. The positive effect of inflation on industrial sector share of total employment may be due to inflation expectation which drives increase in current demand for labour for production of durable goods in the face of rising prices in anticipation of future rise in general price level. It could also be reflection of demand-pull inflation caused by sustained rise in demand over supply which causes industrial firms to raise prices of their output to make more profits. This could have positive effect on employment generation in the industrial sector. This evidence corroborates evidence from Anyanwu (2014) which also found that inflation positively affects youth employment in Africa.

As in the short-run, urban population growth adversely affects industrial sector share of total employment in the long run. This suggests that other sectors of the economy such as agriculture and services may have provided more employment to the rising population than the industrial sector, resulting in decline in the sector's share of total employment in the country. Furthermore, as in the short run, the negative effect on urban population growth in the long run may be attributed to escalation of crime and insecurity in the urban centres. This adversely affects investment; consequently, employment is adversely effected. This finding corroborates evidence from Maijama'a et al. (2019), Afolabi and Awopetu (2020), Adeosun and Popogbe (2020) which found that increase in population worsens the unemployment problem in the country.

\section{Model Diagnostics}

The reliability of the model for policy was tested by performing series of diagnostic tests. The results of the tests are summarized in Table 7.

Table 7: Diagnostic Tests

\begin{tabular}{lll}
\hline Tests & Test Stat & p-value \\
\hline Residual Normality (Jarque-Bera) & 0.6401 & 0.7261 \\
Serial Correlation (B-G LM test) & 0.1561 & 0.3534 \\
Heteroskedasticity (B-P-G) & 0.5492 & 0.8580 \\
Ramsey RESET & 1.9308 & 0.0797 \\
\hline
\end{tabular}

The J-B test for residual normality shows that the residual of the ARDL model are normally distributed. The B-G test for serial correlation indicates that the model has no problem of serial correlation. The B-P-G test result indicates absence of heteroskedasticity problem. The Ramsey RESET shows that the specification of the model is error-free.

\section{Model Stability}

The stability of a model enhances its reliability for policy. This study adopted the test for constancy of regression parameters over-time prescribed by Brown, et al. (1975) to test the stability of the estimated model. The test involves plots of CUSUM and CUSUMSQ. The results are presented in Figures $4 \mathrm{a}$ and $4 \mathrm{~b}$ respectively. 
Figure 4a: CUSUM

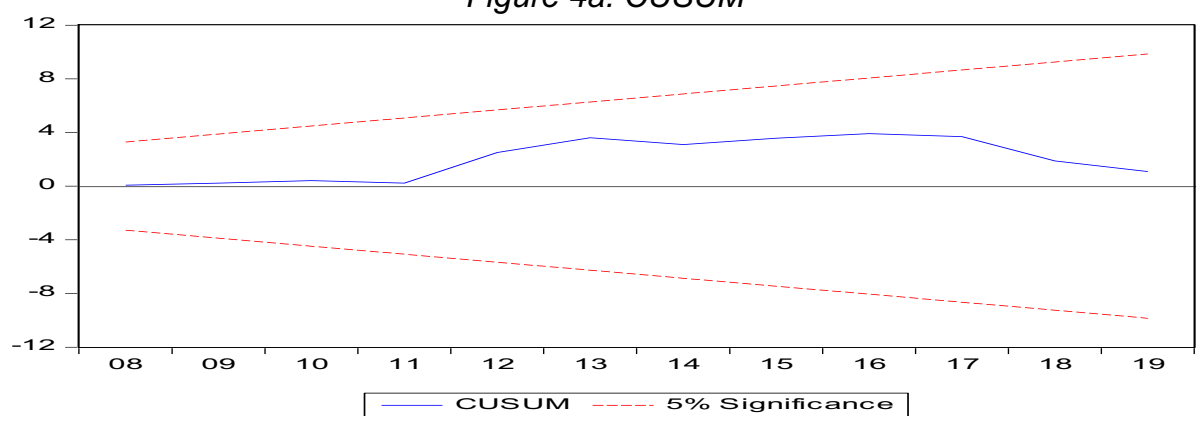

Figure 4b: CUSUMSQ

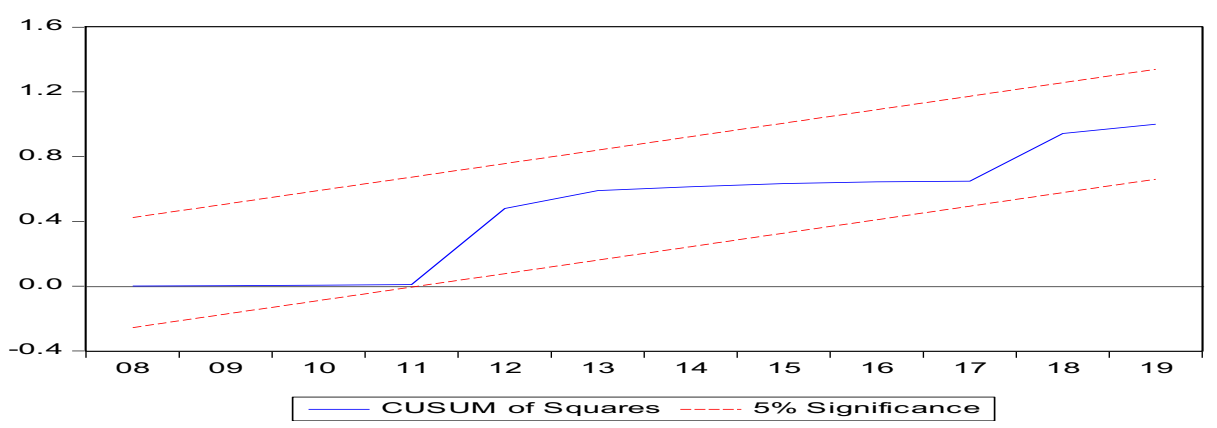

\section{Conclusion and Recommendations}

The employment generation potentials of the implementation of the AfCFTA in Nigeria's industrial sector were empirically examined in this study. The short run and long run effects of expansion in intra-African trade on industrial sector employment were investigated while controlling for the effects of other variables including real effective exchange rate, FDI, trade openness, inflation and urban population growth. The evidence revealed that trade expansion envisaged from the AfCFTA will enhance employment in the country's industrial sector in the short run. However, the effect loses its significance in the long run, though it remains positive. Increase in real effective exchange rate adversely affects employment in Nigeria's industrial sector in the long-run) as it causes increase in inflow of imports of final goods as domestic prices become relatively higher than foreign prices, and adversely affect the competitiveness of the nation's exports. A combination of these effects serves to reduce employment in the nation's industrial sector.

The short run industrial employment effect of integration of Nigeria's economy with the global market by way of openness to global trade was found to be negative and statistically significant. This suggests that openness to trade may have adverse temporary (short run) effect on industrial sector employment. However, its permanent (or long run) effect is positive and statistically significant. With regard to the observed significant short run effect and non-significant long-run industrial sector employment effects of intra-African trade, this observation suggests that while increased intra-African trade could be used to counter the adverse effect of openness to global trade on industrial sector employment in the short-run, it may not be relied upon for long run employment generation in the sector. In this situation, openness to global trade becomes a more appropriate policy option for sustainable employment generation in the industrial sector. This is as a result of knowledge and technology spillover effects of global trade particularly trade with the more advanced or highly industrialised countries of the world which boost productivity and output thereby leading to demand for more labour in the sector.

FDI and urban population growth adversely affected employment generation in the industrial sector in the short- and long-run. Though the short-run effect of inflation on industrial sector employment was negative and non-significant, the long run effect was however positive and significant. This was 
attributed to inflation expectation by industrial firms, which causes them to demand more labour for production (of durable items) in current period in anticipation of future rise in general price level.

In the light of the empirical evidence, the following is recommended for policy consideration:

i.Both intra-African trade and global trade should be seen as complementary tools to enhance employment generation in Nigeria's industrial sector at different time horizons. While effort is made to intensify trade within the African continent, trade with more industrialised countries should also be emphasised in view of the potential productivity, output and employment gains accruing therefrom in the long-run.

ii. The government, through the relevant authorities should strive to keep the real effective exchange rate as low as possible to curb the adverse effect of high real exchange rate on employment. This will require, among others, implementation of monetary and fiscal policies aimed at keeping the domestic prices low relative to price levels of trading partners in order to curb imports, and enhance the competitiveness of the country's exports in both domestic and foreign markets.

iii. There is need for greater (though cautious) integration of the economy with the global market as this would enhance employment generation in the nation's industrial sector in the long run.

iv. The positive, but weak effect of inflation on industrial sector employment suggests that some level of inflation could be favorable to employment generation in the sector. This calls for deployment of policy tools to prevent deflation which may discourage investment and demand for labour. However, there is also need for the monetary authority to ensure that inflation does not get to levels that are injurious to consumption, investment and output as these may turn out to adversely affect employment in the nation's industrial sector.

v. The development of the rural areas (through building of modern infrastructure including energy or electricity, transportation, storage infrastructures, educational and health institutions, etc.) in order to attract investment therein could serve as a check on rural-urban migration. Furthermore, the country's immigration agency (the Nigerian Immigration Service) should be strengthened to prevent illegal immigration. These could curb urban population growth which was found to adversely affect employment generation in the nation's industrial sector.

This study was limited to the implication of the AfCFTA for employment generation in Nigeria's industrial sector. The aggregate employment generation potentials of the AfCFTA as well as its potential to generate employment in other sectors of the economy such as services and agriculture in Nigeria and other countries in the continent of Africa can also be investigated. Future studies may take this study further by performing out-of-sample simulation for values of industrial sector share of total employment in Nigeria vis-a-vis changes in value of total intra-African trade.

\section{References}

Adeosun, O. T. \& Popogbe, O. O. (2020). Population Growth and Human Resource Utilization Nexus in Nigeria. Journal of Humanities and Applied Social Sciences, DOI 10.1108/JHASS-06-20200088. $\quad$ https://www.emerald.com/insight/content/doi/10.1108/JHASS-06-20200088/full/pdf?title=population-growth-and-human-resource-utilization-nexus-in-nigeria

Afolabi, B. \& Awopetu, O. B. (2020). Population Growth and Unemployment in Nigeria. Journal of Economics and Sustainable Development, 11(2), 98-106.

AFREXIM (2019). African Trade Report 2019. African Export-Import Bank.

African Union (2021). Goals \& Priority Areas of Agenda 2063. https://au.int/en/agenda2063/goals

Aigheyisi, O. S. (2019a). Import Competition and Unemployment in Nigeria. AUDCE, 15(4), 208-221.

Aigheyisi, O. S. (2019b). Determinants of FDI inflows to Nigeria: Does Crime Rate Matter? West African Financial and Economic Review, 19(2), 33-60.

Aigheyisi, O. S. \& Iyoha, M. A. (2020). Effects of Foreign Direct Investment and Domestic Investment on Non-Oil Industrial Production in Nigeria. West Africa Financial and Economic Review, 20(2), 1-23.

Akbota, A. \& Baek, J. (2018). The Environmental Consequences of Growth: Empirical Evidence from the Republic of Kazakhstan, Economies, 6(1), 1-11, http://dx.doi.org/10.3390/economies6010019

Akkus, G. E. (2018). The Effects of Trade and Productivity on Employment in the Manufacturing Industry of Turkey. Iktisat Fakültesi Mecmuasi, 64(2), 1-44.

Ani, E. C., Joel, E., Baajon, M. A. (2019). Exchange Rate and Unemployment in Nigeria: An Analysis. International Journal of Family Business and Management, 3(2), 1-7. 
Anyanwu, J. C. (2014). Does Intra-African Trade Reduce Youth Unemployment in Africa? African Development Review, 26(2), 286-309.

Arltová, D. \& Fedorová, M. (2016). Selection of Unit Root Test on the Basis of Length of the Time Series and Value of AR(1) Parameter. Statistika, 93(6), 47-64.

Brown, R. L., Durbin, J. \&, Evans, J. M. (1975). Techniques for Testing the Constancy of Regression Relationships over Time. Journal of the Royal Statistical Society. Series B (Methodological), 37(2), 149-192.

Campos-Vázquez, R. \& J. Rodríguez-López (2011). Trade and Occupational Employment in Mexico since NAFTA. OECD Trade Policy Working Papers, No. 129, OECD Publishing. http://dx.doi.org/10.1787/5kg3nh5q7p5k-en

CIA (2007). Urbanisation, Unemployment and Unrest in the Poor Countries.

https://www.cia.gov/library/readingroom/docs/CIA-RDP79R00967A000500030006-1.pdf.

Choudhry, M. T., Marelli, E. \& Signorelli, M. (2012). Youth Unemployment Rate and Impact of Financial Crises. International Journal of Manpower, 33(1), 76-95.

Dorn, J. A. (2020). The Phillips Curve: A Poor Guide for Monetary Policy. Cato Journal, 40(1), 133151.

Dutt, P., Mitra, D. \& Ranjan, P. (2008). International Trade and Unemployment: Theory and CrossNational Evidence. INSEAD (The Business School for the World) Working Paper, 2008/06/EPS.

Elliott, G., Rothenberg, T. J. \& Stock, J. H. (1996). Efficient tests for an autoregressive unit root. Econometrica 64, 813-836.

Felbermayr, G., Prat, J., \& Schmerer, H. (2008). Globalization and labor market outcomes: wage bargaining, search frictions, and firm heterogeneity. IZA Discussion Papers 3363. Institute for the Study of Labor (IZA).

Frankel, M. (1962). The Production Function in Allocation and Growth: A Synthesis. American Economic Review 52, 995-1022.

Harris, R. \& Sollis, R. (2003). Applied Time Series Modelling and Forecasting. Wiley.

Herath, H. M. S. P. (2014). The Impact of International Trade on Employment Generation: A Sri Lankan Experience. International Journal of Economics, Commerce and Management, 2(7), $1-8$.

Idris, Z. Z., Ismail, N. W., Ibrahim, S. \& Hamzah, H. Z. (2020). The Impact of High-Technology Trade on Employment. The Journal of International Trade and Economic Development. https://doi.org/10.1080/09638199.2020.1852301

ILO (1996, May 29). Unemployment Threatens World Cities; Jobs are Needed to Check Growth

in Urban Poverty, Says ILO. Press release. https://www.ilo.org/global/about-theilo/newsroom/news/WCMS 008055/lang--en/index.htm).

Jha, P., Lee, J. Y., Liang, Y. \& Mitra, D. (2019). International Trade and Employment: Theory and Evidence from Korean Firms. https://www.economics.uci.edu/research/wp/1920/19-20-02.pdf

Kemal, M. A. \& Qadir, U. (2005). Real Exchange Rate, Exports, and Imports Movements: A Trivariate Analysis. The Pakistan Development Review, 44(2), 177-195.

Kharroubi, E. (2011). The Trade Balance and the Real Exchange Rate. BIS Quarterly Review, September 2011, 33-42.

Kim, J. (2011). The Effects of Trade on Unemployment: Evidence from 20 OECD countries. http://www2.ne.su.se/paper/wp11 19.pdf

Kpognon, K., Ondoa, H. A. \& Bah, M. (2020). Trade Openness and Youth Employment in SubSaharan Africa. Journal of Economic Integration, 35(4), 751-777.

Lysenko, D. (2018). The Long-Run Effects of the Real Exchange Rate on Employment and Wages in Canadian Manufacturing. International Review of Applied Economics, 33(4), 477-504.

Maijama'a, R., Musa, K. S. \& Yakubu, M. \& Mohammed, N. (2019). Impact of Population Growth on Unemployment in Nigeria: Dynamic OLS Approach. Journal of Economics and Sustainable Development, 10(22), 79-88.

Matusz, S. J. (1996). International Trade, the Division of Labor, and Unemployment. International Economic Review, 37(1), 71-84.

Nchom, H. \& Udeorah, S. A. F. (2021). International Trade and Employment in Nigeria. Journal of Research in Humanities and Social Science, 9(3), 1-6.

Nwaka, I. D., Uma, K. E. \& Tuna, G. (2015). Trade openness and unemployment: Empirical evidence for Nigeria. The Economic and Labour Relations Review, 26(1), 117-136.

OEC (2021). Country Profile: Nigeria. The Observatory of Economic Complexity. https://oec.world/en/profile/country/nga 
Ojekule, A. (2019, August 27). These are the 7 biggest exporting countries in Africa right now. https://www.pulse.ng/bi/finance/these-are-the-7-biggest-exporting-countries-in-africa-rightnow/x24jil14

Onimisi, A. T. (2014). Foreign Direct Investments and Employment Generation Nexus in Nigeria. Journal of Educational and Social Research, 4(5), 119-128.

Pesaran, M. H., Shin, Y. \& Smith, R. (2001). Bounds Testing Approaches to the Analysis of Level Relationships. Journal of Applied Econometrics, 16, 289-326.

Phillips, A. W. (1958). The Relation between Unemployment and the Rate of Change of Money Wage Rates in the United Kingdom, 1861-1957. Economica, 25(100), 283-299.

Polat, O. \& Uslu, E. E. (2011). Impact of international trade on employment in manufacturing industry of Turkey. African Journal of Business Management, 5(13), 5127-5135.

Rajesh, R. S. N. \& Subash, S. (2015). Impact of Foreign Trade on Employment and Wages in Indian Manufacturing. South Asia Economic Journal, 16(2), 209-232. https://doi.org/10.1177/1391561415598457

Sanchez-Reaza, J., Grover, R., Lord, N. C. (2016, June 13). Looking at urbanization through a

jobs lens. World Bank Blog. https://blogs.worldbank.org/jobs/looking-urbanization-through-jobs-lens.

Solow, R. M. (1956). A Contribution to the Theory of Economic Growth. The Quarterly Journal

of Economics, 70(1), 65-94.

Songwe, V. (2019). Intra-African Trade: A Path to Economic Diversification and Inclusion. In: Boosting Trade and Investment: A new agenda for regional and international engagement (Chapter 6, pp. 97-116), Brookings.

Tobin, J. (1972). Inflation and Unemployment. American Economic Review, 62, 1-18.

Ubaldo, M. D. \& Winters, L. A. (2020). International Trade Regulation and Job Creation. IZA World of Labour.

UNCTAD (2013). The Impact of Trade on Employment and Poverty Reduction. The United Nations.

UNCTAD (2019). Economic Development in Africa Report 2019. The United Nations Conference on Trade and Development.

UNCTAD (2020). Trade, Employment and Development. https://unctad.org/topic/tradeagreements/trade-employment-and-development

United Nations (2021). The Sustainable Development Goals Report 2021. The United Nations

UNU-CRIS (2020). Regional Integration Knowledge System. United Nations University.

Ventura, L. (2020, July 22). Poorest Countries in the World 2020. Global Finance Magazine. https://www.gfmag.com/global-data/economic-data/the-poorest-countries-in-the-world

Wadhwani, S. B. (1987). The Effects of Inflation and Real Wages on Employment. Economica, 54(213), 21-40.

Wiebusch, M. (2012). Urban Development and Effects on Employment. KFW Position Paper,

July $12 . \quad$ https://www.kfw-entwicklungsbank.de/Download-Center/PDF-DokumentePositionspapiere/2012 07 Besch\%C3\%A4ftigung Stadtentwicklung EN.pdf

Workman, D. (2019). Top African Export Countries. https://www.worldstopexports.com/top-africanexport-countries/

World Bank (2020a). The African Continental Free Trade Area Economic and Distributional Effects. The World Bank. https://openknowledge.worldbank.org/bitstream/handle/10986/34139/9781464815591.pdf

World Bank (2020b). World Development Indicators. The World Bank.

World Population Review (2021). Richest African Countries 2021. https://worldpopulationreview.com/country-rankings/richest-african-countries

Yanikkaya, H. (2013). Is Trade Liberalization a Solution to the Unemployment Problem? Portuguese Economic Journal, 12, 57-85. 